Огляди літератури, оригінальні дослідження, погляд на проблему

УДК 616.24-089.87-02:616.149-008.341.1]-092.9

DOI 10.11603/1811-2471.2017.v1.i3.8034

\title{
МОРФОФУНКЦІОНАЛЬНА ПЕРЕБУДОВА ВЕНОЗНОГО РУСЛА ПЕРЕДСЕРДЬ ЛЕГЕНЕВОГО СЕРЦЯ
}

\author{
ДВНЗ «Тернопільський державний медичний університет імені І. Я. Горбачевського МОз України»
}

РЕЗЮМЕ. Вступ. В останні роки клініцисти та морфологи почали звертати увагу на легеневе серце. Варто зазначити, що патогенез хронічного легеневого серця складний і досить багатогранний, що значною мірою ускладнює своєчасну діагностику легеневої артеріальної гіпертензії та хронічного легеневого серця. Відомо, що вказана патологія перебігає на фоні змін тонусу венозних судин. Водночас морфофункціональні особливості венозної системи передсердь легеневого серця вивчені недостатньо.

Мета роботи - дослідження морфофункціональних особливостей венозного русла передсердь легеневого серця.

Матеріал і методи. Комплексом морфологічних методів досліджені вени лівого та правого передсердь серця 19 статевозрілих свиней-самців в'єтнамської породи, які були поділені на 3 групи. 1 група нараховувала 6 інтактних дослідних тварин, 2 - 8 свиней з артеріальною легеневою гіпертензією та компенсованим легеневим серцем, 3 - 5 тварин з артеріальною легеневою гіпертензією та декомпенсацією легеневого серця. Артеріальну легеневу гіпертензію та легеневе серце моделювали шляхом виконання правосторонньої пульмонектомії. Евтаназію дослідних тварин здійснювали кровопусканням в умовах тіопентал-натрієвого наркозу через місяць від початку експерименту. Проводили окреме зважування та планіметрію камер серця. Венозне русло частини сердець заповнювали туш-желатиновою сумішшю через устя вінцевих артерій. 3 лівого та правого передсердь вирізали шматочки, які фіксували у 10 \% нейтральному розчині формаліну і після відповідного проведення через етилові спирти зростаючої концентрації поміщали у парафін. Мікротомні зрізи товщиною 5-7 мкм фарбували гематоксиліном-еозином, за ванГізон, Маллорі, Вейгертом, толуїдиновим синім. Гістологічні мікропрепарати досліджували за допомогою мікроскопів МБД-15 та Люмам-Р8.

Результати. Окремим зважуванням та планіметрією камер серця встановлено, що через місяць після правосторонньої пульмонектомії зростали маса частин серця та їхні просторові характеристики з домінуванням гіпертрофії та дилатації правого шлуночка. Отримані результати свідчили про розвиток легеневого серця.

Встановлено, що у пострезекційному компенсованому легеневому серці структура вен лівого та правого передсердь суттєво змінювалася. У змодельованих патологічних умовах у більшості випадків досліджувані структури розширені, переповнені кров'ю. Спостерігався також перивазальний набряк, який міг здавлювати вени, звужувати просвіт та деформувати досліджувані судини. Виявлялася дистрофія гладких м'язових клітин, ендотеліоцитів та місцями десквамація останніх. Деякі ендотеліоцити та гладкі міоцити з явищами набряку, межі між ними нечіткі, частина клітин збільшена у розмірах, дистрофічно і некробіотично змінені. При декомпенсації легеневого серця описані вище структурні зміни вен були виражені більшою мірою. Переважна більшість венозних судин розширені, переповнені форменими елементами крові, з явищами стазу, що свідчило про виражене порушення їх дренажної функції. Венули при цьому нерідко починалися у вигляді ампул, у які впадали розширені, часто повнокровні посткапіляри у вигляді китиць. Венозний застій у досліджуваних судинах призводив до посилення гіпоксії, дистрофії та некрозів кардіоміоцитів, інфільтративних та склеротичних процесів. Виявлені структурні зміни домінували у правому передсерді декомпенсованого легеневого серця.

Висновок. Пострезекційна легенева гіпертензія та легеневе серце призводять до вираженої структурної перебудови венозного русла передсердь, що характеризується розширенням, повнокров'ям, деформацією просвіту венозних структур, порушенням їх венозної дренажної функції, посиленням гіпоксії та деструктивних процесів у міокарді, які домінують у правому передсерді декомпенсованого легеневого серця.

ключОВІ слОВА: вени; передсердя; легеневе серце.

Вступ. В останні роки клініцисти та морфологи почали звертати увагу на легеневе серце. Проблема останнього сьогодні набуває все більшого значення у зв'язку із стрімким збільшенням кількості хронічних обструктивних захворювань легень, хронічних форм туберкульозу легень, професійних патологій легень, при яких основною причиною втрати працездатності і скорочення життя хворих $\epsilon$ декомпенсація хронічного легеневого серця $[2,4,6,8]$.

Варто зазначити, що патогенез хронічного легеневого серця складний і досить багатогран- ний, що значною мірою ускладнює своєчасну діагностику легеневої артеріальної гіпертензії та хронічного легеневого серця $[2,7,9]$. Відомо, що вказана патологія перебігає на фоні змін тонусу венозних судин. Водночас морфофункціональні особливості венозної системи передсердь легеневого серця вивчені недостатньо.

Метою даної роботи стало дослідження морфофункціональних особливостей венозного русла передсердь легеневого серця.

Матеріал і методи. Комплексом морфологічних методів досліджені вени лівого та правого 
Огляди літератури, оригінальні дослідження, погляд на проблему

передсердь серця 19 статевозрілих свиней-самців в'єтнамської породи, які були поділені на 3 групи. 1 група нараховувала 6 інтактних дослідних тварин, 2 - 8 свиней з артеріальною легеневою гіпертензією та компенсованим легеневим серцем, 3 5 тварин з артеріальною легеневою гіпертензією та декомпенсацією легеневого серця. Остання характеризувалася синюшністю видимих слизових оболонок, периферійними і порожнинними набряками (асцит, гідроторакс, гідроперикард), застійними явищами у органах великого кола кровообігу.

Артеріальну легеневу гіпертензію та легеневе серце моделювали шляхом виконання правосторонньої пульмонектомії [6]. Евтаназію дослідних тварин здійснювали кровопусканням в умовах тіопентал-натрієвого наркозу через місяць від початку експерименту. Усі маніпуляції та евтаназію свиней проводили з дотриманням принципів роботи з експериментальними тваринами. Виконували окреме зважування та планіметрію камер серця $[1,6]$. Венозне русло частини сердець заповнювали туш-желатиновою сумішшю через устя вінцевих артерій. 3 лівого та правого передсердь вирізали шматочки, які фіксували у 10 \% нейтральному розчині формаліну і після відповідного проведення через етилові спирти зростаючої концентрації поміщали у парафін. Мікротомні зрізи товщиною 5-7 мкм фарбували гематоксиліном-еозином, за ванГізон, Маллорі, Вейгертом, толуїдиновим синім. Гістологічні мікропрепарати досліджували за допомогою мікроскопів МБД-15 та Люмам-Р8.

Результати й обговорення. Окремим зважуванням та планіметрією камер серця встановлено, що через місяць після правосторонньої пульмонектомії зростали маса частин серця та їхні просторові характеристики з домінуванням гіпертрофії та дилатації правого шлуночка. Отримані результати свідчили про розвиток легеневого серця.

Більшість морфологів вважають, що вени серцевого м'яза починаються із венозної ланки гемомікроциркуляторного русла (посткапілярів та венул) $[3,5]$. Деякі дослідники поділяють вени серцевого м'яза на інтраорганні та підепікардіальні. Внутрішньоорганні вени неушкодженого міокарда за структурою суттєво відрізняються від вінцевих артерій. У внутрішньоорганних венах міокарда складно провести межу між внутрішнім, середнім та зовнішнім шарами судинної стінки. Стінки закапілярних венул представлені ендотелієм на базальній мембрані. У вказаній структурі дрібних вен, крім ендотеліоцитів та базальної мембрани, локалізувалися також гладком'язові клітини, еластичні та колагенові волокна. Завдяки названим зовнішнім структурам вказані вени вже не беруть участі в обмінних процесах, а відіграють важливу дренажну функцію. Варто також зазначити, що гладкі м'язові клітини у стінках вен можуть мати різні варіанти. У деяких осередках вен вони повністю відсутні, а в інших - розміщуються в один шар. У місцях злиття вен м'язові елементи можуть розміщатися у 2-3 шари. Вмістимість вен значно перевищує артеріальну. Вміст крові у венах серця може суттєво збільшуватися завдяки спіралеподібній локалізації м'язових пучків у венозних структурах.

Встановлено, що у пострезекційному компенсованому легеневому серці структура вен лівого та правого передсердь суттєво змінювалася. У змодельованих патологічних умовах у більшості випадків досліджувані структури розширені, переповнені кров'ю. Спостерігався також перивазальний набряк, який міг здавлювати вени, звужувати просвіт та деформувати досліджувані судини. Виявлялася дистрофія м'язових клітин, ендотеліоцитів та, місцями, десквамація останніх. Деякі ендотеліоцити та гладкі міоцити з явищами набряку, межі між ними нечіткі, частина клітин збільшена у розмірах, наявні дистрофічні та некробіотичні зміни (рис. 1).

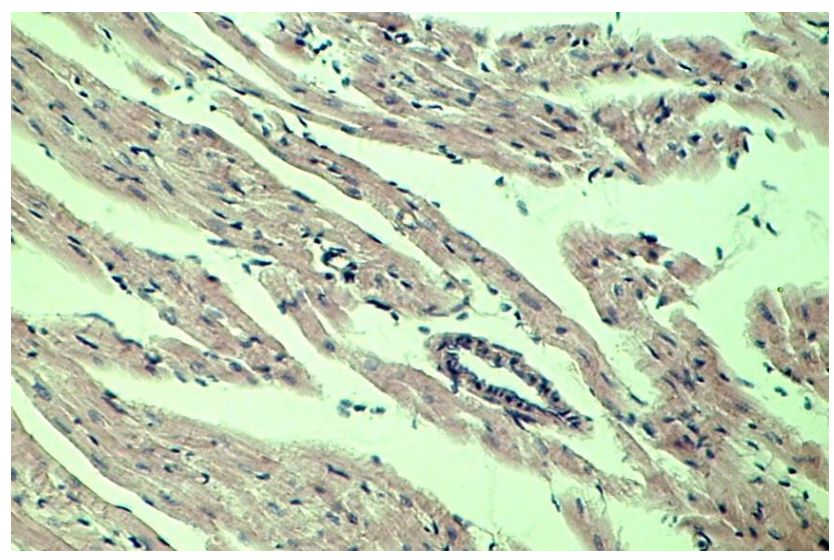

Рис. 1. Виражені перивазальні та стромальні набряки, деформований просвіт вени, дистрофічні зміни міоцитів, ендотеліоцитів, осередки десквамації останніх, вогнища дистрофії кардіоміоцитів у правому передсерді компенсованого легеневого серця. Забарвлення гематоксиліном-еозином. 36.: × 125.

У деяких досліджуваних судинах спостерігали осередки з проліферацією ендотеліоцитів. Згідно з даними переважної більшості дослідників, проліферація ендотеліальних клітин свідчить про наявність вираженої гіпоксії у органах. В ядрах вказаних клітин виявляли гіпохроматоз, пікноз та осередки лізису.

Місцями контури стінок вен нечіткі, у них відмічалися чергування набряклих та склеротичних вогнищ, а також чергування гіпертрофованих та стоншених ділянок. Порушення венозного відто- 
Огляди літератури, оригінальні дослідження, погляд на проблему

ку, депонування крові у венах супроводжується зростанням опору її руху, що призводить до гіпертрофії м'язової оболонки не тільки артеріол і артерій, але і деяких вен $[3,5]$, що мало місце у наших спостереженнях. Ці явища відображають вено-артеріальну реакцію, яка направлена на збереження повноцінної мікроциркуляції у досліджуваному органі. Контури вен з нерівномірним просвітом, звивисті, покручені, їх звужені осередки з гіалінізованими стінками інколи чергувалися з розширеними ділянками. Наведене свідчить, що змодельований експериментальний патологічний процес призводить до вираженої структурної перебудови всього венозного русла передсердь легеневого серця, тобто до структурно-функціональних змін всіх ланок їх венозної дренажної системи.

При декомпенсації легеневого серця описані вище структурні зміни вен були виражені більшою мірою. Переважна більшість венозних судин розширені, переповнені форменими елементами крові, з явищами стазу, що свідчило про виражене порушення їх дренажної функції $[3,9]$. Венули при цьому нерідко починалися у вигляді ампул, у які впадали розширені, часто повнокровні посткапіляри (рис. 2), або у вигляді китиці.

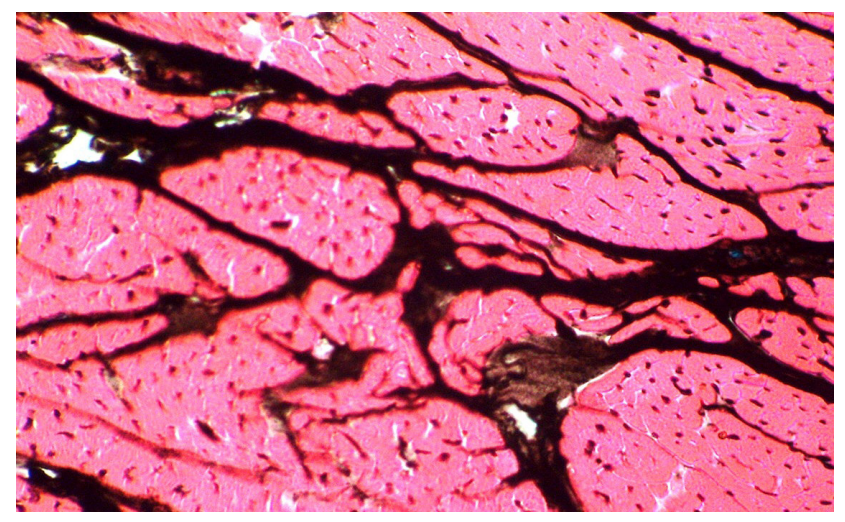

Рис. 2. Розширення та повнокров'я венозних структур гемомікроциркуляторного русла (закапілярних венул та венул), стромальний набряк, осередки дистрофії кардіоміоцитів у стінці правого передсердя декомпенсованого легеневого серця. Туш-желатинова ін'єкція судин. 36.: х 125.

Локалізація вказаних структур була різною: паралельно та перпендикулярно по відношенню до м'язових волокон міокарда. В деяких дрібних інтрамуральних венах відмічалася помірно виражена гіпертрофія м'язової оболонки з посиленим розвитком поздовжнього м'язового шару, локалізованим всередину від медії. Стромальні, перивазальні набряки та крововиливи свідчили про підвищену проникність венозних стінок (рис. 3, 4).

Венозний застій у досліджуваних судинах призводив до посилення гіпоксії, дистрофії та не- крозів кардіоміоцитів, інфільтративних та склеротичних процесів. Виявлені структурні зміни домінували у правому передсерді декомпенсованого легеневого серця.

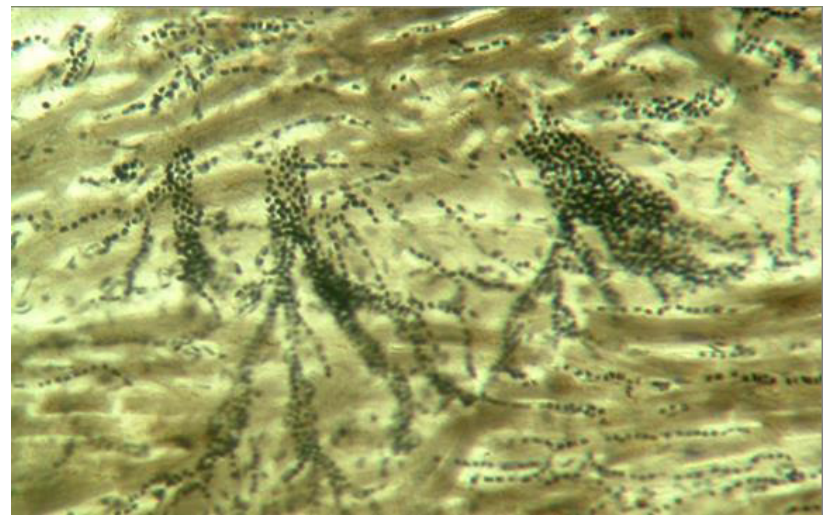

Рис. 3. Стази у судинах гемомікроциркуляторного русла з вираженим розширенням венозних структур, перивазальний та стромальний набряки, осередки крововиливів у правому передсерді декомпенсованого легеневого серця. Забарвлення за Гейденгайном. 36.: х 125.

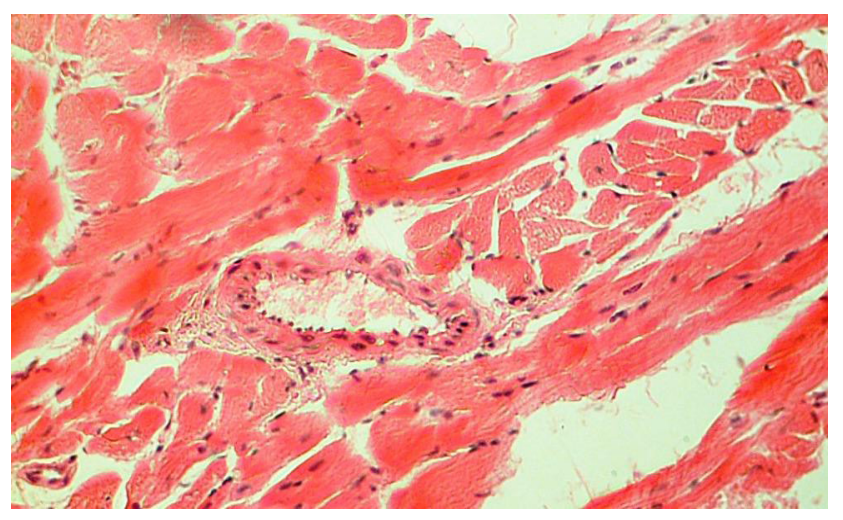

Рис. 4. Перивазальний та стромальний набряки, зміни архітектоніки, осередки дистрофії міоцитів, ендотеліоцитів у венозній стінці, вогнища вакуольної дистрофії кардіоміоцитів у лівому передсерді декомпенсованого легеневого серця. Забарвлення гематоксиліном-еозином. 36.: х 140.

Висновок. Пострезекційна легенева артеріальна гіпертензія та легеневе серце призводять до вираженої структурної перебудови венозного русла передсердь, що характеризується розширенням, повнокров'ям, деформацією просвіту венозних структур, порушенням їх венозної дренажної функції, посиленням гіпоксії та деструктивних процесів у міокарді, які домінують у правому передсерді декомпенсованого легеневого серця.

Перспективи подальших досліджень. Детальне усестороннє вивчення особливостей ремоделювання венозного судинного русла передсердь легеневого серця необхідне для його врахування при діагностиці, корекції та розробці профілактики уражень міокарда. 
Огляди літератури, оригінальні дослідження, погляд на проблему

\section{ЛІТЕРАТУРА}

1. Автандилов Г. Г. Основы количественной патологической анатомии / Г. Г. Автандилов. - М. : Медицина, 2002. -240 с.

2. Амосова К. М. Клінічний перебіг та стан міокарда унаслідок хронічної обструктивної патології легень, залежно від наявності легеневої гіпертензії / К. М. Амосова, Д. Ф. Конопльова, І. Д. Мазур // Серце і судини. 2009. - № 2. - С. 48-52.

3. Байбаков В. М. Морфофункціональні зміни венозного русла як ланки дренажної системи яєчка при травмуванні судинних анастомозів сім'яного канатика в експерименті / В. М. Байбаков // Клінічна анатомія та оперативна хірургія. - 2011. - Т. 10, № 4. - С. 32-35.

4. Гаврисюк В. К. Хроническое легочное серце / В. К. Гаврисюк, Н. Е. Моногарова // Новости медицины и фармации. - 2008. - № 256. - С. 29-31.

5. Гаджиева Н. А. Особенности ремоделирования миокарда левого желудочка при туберкулёзе у под-

\section{REFERENCES}

1. Avtandilov, G.G. (2002). Osnovy kolichestvennoy patologicheskoy anatomii [Basics of quantitative pathological anatomy]. Moscow: Meditsina [in Russian].

2. Amosova, K.M., Konopleva, L.F. \& Mazur, I.D. (2009). Klinichnyi perebih ta stan miokarda z khronichnym lehenevym sertsem unaslidok khronichnoi obsruktyvnoi patolohii lehen zalezhno vid naiavnosti lehenevoi hipertenzii [Clinical course and condition of myocardium with chronical cor pulmonale as a result of chronical obstructive pathology of lung depending on existence of pulmonary hypertension]. Sertse i sudyny- Heart and Vessels, 2, 48-52.

3. Baibakov, V.M. (2011). Morfofunktsionalni zminy venoznoho rusla yak lanky drenazhnoi systemy yaiechka pry travmuvanni sudynnykh anastomosiv simianoho kanatyka v eksperymenti [Morphofunctoinal changes of venous bed as a link of drenage system of testis when trauma of vessel anastomosis of spermatic cord in experiment]. Clinichna anatomiia i operatyvna khirurhiia - Clinical Anatomy and Operative Surgery, 10, 4, 32-35.

4. Havrysiuk, V.K., Havrysiuk, V.K. \& Monoharova, N.E. (2008). Khronicheskoe legechnoe serdtse [Chronical cor pulmonale]. Novosti meditsyny i pharmatsyi-News of Medicine and Pharmacology, 256, 29-36. ростков / Н. А. Гаджиева // Український кардіологічний журнал. - 2010. - № 4. - С. 84-87.

6. Гнатюк М. С. Особливості просторової перебудови камер легеневого серця / М. С. Гнатюк, Л. В. Татарчук, О. Б. Ясіновський // Клінічна анатомія та оперативна хірургія. - 2010. - № 9. - С. 45-48.

7. Коноплева Л. Ф. Хроническое легочное серце: проблемы классификации, диагностики и лечения / Л. Ф. Коноплева // Здоров'я України. - 2011. - № 1 (13). С. 24-26.

8. Норейко Б. В. Лечение хронического легочного сердца / Б. В. Норейко // Новости медицины и фармации. - 2011. - № 10. - С. 12-15.

9. Barnes P. Y. Chronic obstructive pulmonary disease molecular and cellular mechanisms / P. Y. Barnes, D. Shapiro, R. A. Pamwels // Eur. Respirat. J. - 2003. - Vol. 22. P. $672-678$
5. Gadzhiyeva, N.A. (2010). Osobennosti remodelirovaniya miokarda levogo zheludochka pri tuberkuloze $v$ podrostkov [Peculiarities of remodeling myocardium of left ventricle at tuberculosis in teenagers]. Ukrainskyi kardiolohichnyi zurnal - Ukranian Cardiological Journal, 4, 8487 [in Russian].

6. Hnatiuk, M.S. (2010). Osoblyvosti prostorovoi perebudovy kamer lehenevoho sertsia [Peculiarities of spatial reconstruction of chambers of cor pulmonale]. Clinichna anatomiia i operatyvna khirurhiia - Clinical Anatomy and Operative Surgery, 9, 45-48.

7. Konopleva, L.F. (2011). Khronicheskoe legechnoe serdtse: problemy klasifikatsyi diagnistiki i lecheniya [Chronical cor pulmonale: problems of classifications, diagnostics and treatment]. Zdorovia Ukrainy - Health of Ukraine, 1 (13), 24-26 [in Russian].

8. Noreyko, B.V. Lecheniya khronicheakogo legechnogo serdtsa [Treatment of chronical cor pulmonale]. Novosti meditsyny i pharmakologii - News of Medicine and Pharmacology, 10, 12-15 [in Russian].

9. Barnes, P.Y., Shapiro, D.R. \& Pamwels, A. (2003). Chronic obstructive pulmonary disease molecular and cellular mechanisms. Eur. Respirat. J., (22), 672-678.

\title{
МОРФОФУНКЦИОНАЛЬНАЯ ПЕРЕСТРОЙКА ВЕНОЗНОГО РУСЛА ПРЕДСЕРДИЙ ЛЕГОЧНОГО СЕРДЦА
}

\author{
๑о. Б. Слабый
}

\author{
ГВУз «Тернопольский государственный медицинский университет имени И. Я. Горбачевского \\ МЗ Украины»
}

РЕЗЮМЕ. Введение. В последние годы клиницисты и морфологи начали все чаще интересоваться легочным сердцем. Необходимо указать, что патогенез хронического легочного сердца сложный и достаточно многогранный, что значительно осложняет своевременную диагностику легочной артериальной гипертензии и хронического легочного сердца. Известно, что указанная патология протекает на фоне изменений тонуса 
Огляди літератури, оригінальні дослідження, погляд на проблему

венозных сосудов. В то же время морфофункциональные особенности венозной системы предсердий легочного сердца изучены недостаточно.

Целью представленной работы было исследование морфофункциональных особенностей венозного русла предсердий легочного сердца.

Материал и методы. Комплексом морфологических методов исследованы вены левого и правого предсердий сердца 19 половозрелых свиней-самцов вьетнамской породы, которые были разделены на 3 группы. 1 группа насчитывала 6 интактных исследуемых животных, 2 - 8 свиней с артериальной легочной гипертензией и компенсированным легочным сердцем, 3 - 5 животных с артериальной легочной гипертензией и декомпенсированным легочным сердцем. Артериальную легочную гипертензию и легочное сердце моделировали путем выполнения правосторонней пульмонэктомии. Эвтаназию экспериментальных животных осуществляли кровопусканием в условиях тиопентал-натриевого наркоза через месяц от начала эксперимента. Проводили раздельное взвешивание и планиметрию камер сердца. Венозное русло части сердец заполняли туш-желатиновой смесью через устья венечных артерий. Из левого и правого предсердий вырезали кусочки, которые фиксировали в 10 \% нейтральном растворе формалина и после соответствующего проведения в этиловых спиртах возростающей концентрации помещали у парафин. Микротомные срезы толщиной 5-7 мкм красили гематоксилиномэозином, по ванГизон, Маллори, Вейгерту, толуидиновым синим. Гистологические препараты исследовались при помощи микроскопов МБИ-15 и Люмам-Р8.

Результаты. Отдельным взвешиванием и планиметрией камер сердца выявлено, что через месяц после правосторонней пульмонэктомии увеличились масса частей сердца и их пространственные характеристики с доминированием гипертрофии и дилатации правого желудочка. Полученные результаты свидетельствовали о развитии легочного сердца. Констатировано, что в пострезекционном компенсированном легочном сердце существенно изменялась структура вен левого и правого предсердий. В смоделированных патологических условиях исследуемые сосуды расширены, переполнены кровью, наблюдался также перивазальный отек, который сдавливал вены, сужал просвет и деформировал их. Наблюдалась дистрофия миоцитов, стромальных структур, эндотелиоцитов и десквамация местами последних. Некоторые эндотелиоциты и гладкие миоциты с явлениями отека, границы между ними нечеткие, часть клеток увеличенных размеров, дистрофически и некробиотически изменены. При декомпенсации легочного сердца описанные выше структурные изменения больше выражены. Большинство венозних сосудов расширены, переполнены форменными элементами крови, с явлениями стаза, что свидетельствовало о выраженном нарушении их дренажной функции. Венулы при этом расширены, начинались в виде ампул, в которые собирались грозди посткапилляров. Венозное полнокровие исследуемых сосудов приводило к усилению гипоксии, дистрофии, некрозов кардиомиоциов, инфильтративных и склеротических процессов, которые доминировали в правом предсердии декомпенсированного легочного сердца.

Выводы. Пострезекционная легочная гипертензия и легочное сердце приводят к выраженной структурной перестройке венозного русла предсердий, что характеризуется расширением, полнокровием, деформацией просвета венозних структур, нарушением их венозной дренажной функции, усилением гипоксии и деструктивных процессов в миокарде, которые доминируют в правом предсердии декомпенсированного легочного сердца.

КЛЮчЕВЫЕ СЛОВА: вены; предсердия; легочное сердце.

\section{MORPHOFUNCTIONAL RESTRUCTURING OF VENOUS BED ATRIA OF COR PULMONALE} ๑O. B. Slabyi

\section{Horbachevsky Ternopil State Medical University}

SUMMARY. Introduction. In recent years clinicians and morphologists began to pay attention of cor pulmonale. It should be noted that pathogenesis of chronic cor pulmonale is difficult and many-sided enough, that complicates timely diagnostics of pulmonary hypertension and chronic cor pulmonale largely. It is known that the indicated pathology runs across on the background of changes of tone of venous vessels. The morphofunctional feature not enough of the venous system of atria of cor pulmonale is studied at the same time.

The aim of this work became research of morphofunctional features venous bed of atria of cor pulmonale.

Materials and Methods. The complex of morphological methods investigated veins of the left and right atria of heart 19 puberty pigs-males of the Vietnamese breed, that were divided into 3 groups. Group 1 counted 6 intact experience animals, group $2-8$ pigs with a pulmonary hypertension and compensated cor pulmonale, $3-5$ animals with a pulmonary hypertension and decompensated cor pulmonale. A pulmonary hypertension and cor pulmonale was designed by a way to implementations of right-side pulmonectomy. Euthanasia of experience animals was carried out by bloodletting in the conditions of thiopental-natrium anesthesia through a month from the beginning of experiment. There was conducted the separate weighing and planimetry of cardiac chambers. The venous bed of part of hearts was filled by India-ink-gelatin mixture through coronary arteries. From left and right atria cut out pieces that fixed in $10 \%$ neutral solution of formalin and after corresponding realization through the ethyl spirits of growing concentration placed in a paraffin. Microthomical cuts in thick 5-7 $\mathrm{\mu m}$ dyed of hematoxylin-eozinum, methods van-Gizon, Mallory, Veigert, toluidin blue. Histological microslides were investigated by means of microscopes of MBI- 15 and Lumam-P8. 
Огляди літератури, оригінальні дослідження, погляд на проблему

Results and Discussion. It is set the separate weighing and planimetry of cardiac chambers showed, that through a month after right pulmonectomy mass of parts of heart and their spatial descriptions grew with prevailing of hypertrophy and dilatation of right ventricle. The got results testified to development of pulmonary heart. It is set that in postresection the compensated cor pulmonale the structure of veins of left and right atrium changed substantially. In the modelled pathological terms in most cases the investigated structures are extended, overwhelmed with blood. We also observed perivasal edema, that could squeeze veins, narrow a road clearance and deform the investigated vessels. Dystrophy of smooth myocytes appeared, endotheliocytes and desquamation placed of the last. Some endotheliocytes and smooth myocytes with the phenomena of edema, limit between them unclear, part of myocytes is megascopic in sizes, dystrophic, necrobiotic changed. During decompensation of cor pulmonale the structural changes of veins are described higher and shown in a greater degree. Majority of venous vessels is extended, overwhelmed with hemocytes, with the stasis, that testified to the expressed violation them drainage function. Venules here quite often began as ampoules the extended, often sanguineous post-capillaries fell in that, or as a brush. Venous stagnation in the investigated vessels resulted in strengthening of hypoxia, dystrophy and necrosis of cardiomyocytes, infiltration and sclerotic processes. The educed structural changes prevailed in right atrium of the decompensated cor pulmonale.

Conclusions. Post-resection pulmonary hypertension and cor pulmonale result in the expressed structural alteration of venous bed of atrium, that is characterized by expansion, sanguineous, by deformation of road clearance of venous structures, violation of them venous drainage function, strengthening of hypoxia and destructive processes in myocardium, that prevail in the right auricle of the decompensated cor pulmonale.

KEY WORDS: veins; atria; pulmonary heart. 